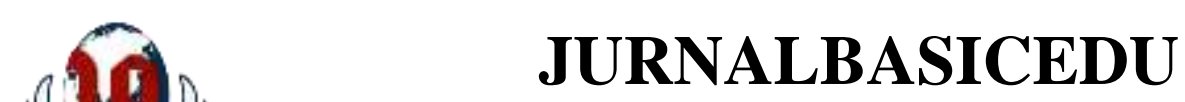

Volume 5 Nomor 6 Tahun 2021 Halaman 5379 - 5385

Research \&Learningin Elementary Education https://jbasic.org/index.php/basicedu

PMALRSITAS

\title{
Pengaruh Kemampuan Berpikir Kreatif terhadap Kemampuan Menulis Karangan Deskripsi
} Siswa Sekolah Dasar

\author{
Yanti Arasi Sidabutar \\ Universitas HKBP Nommensen Pematangsiantar, Indonesia \\ E-mail: arasiyanti@gmail.com
}

\begin{abstract}
Abstrak
Upaya untuk meningkatkan kemampuan menulis karangan deskripsi adalah dengan memperhatikan kemampuan berpikir kreatif siswa. Tujuan dari penelitian ini untuk melihat bagaimana pengaruh kemampuan berpikir kreatif siswa terhadap hasil menulis karangan deskripsi. Metode penelitian yang dipakai dalam penelitian adalah penelitian eksperimen deskriptif kuantitatif. Subjek dalam penelitian ini yang mana sebagai penerima tindakan ialah seluruh siswa kelas V SDN 091539 Hutabayu pada tahun ajaran 2019-2020, dan guru kelas V SDN 091539 Hutabayu sebagai pelaku tindakan. Teknik pengumpulan data dalam penelitian ini menggunakan angket berpikiri kreatif dan essai tes untuk menguji kemampuan menulis karangan deskripsi. Prosedur penelitian ini yaitu pengisian angket kemampuan berpikir kreatif, melakukan pretes, pelaksanaan tindakan, dan melakukan postes. Hasil penelitian ini menunjukan nilai hasil belajar karangan deskripsi siswa dengan kemampuan berpikir kreatif tinggi lebih tinggi daripada nilai siswa dengan kemampuan berpikir kreatif rendah.
\end{abstract}

Kata Kunci: Berpikir Kreatif, Hasil Belajar,Karangan Deskripsi

\begin{abstract}
Efforts to improve the ability to write descriptive essays are to pay attention to students' creative thinking skills. The purpose of this study was to see how the influence of students' creative thinking skills on the results of writing descriptive essays. The research method used in this research is descriptive quantitative experimental research. The subjects in this study who were the recipients of the action were all fifth grade students at SDN 091539 Hutabayu in the 2019-2020 school year, and fifth grade teachers at SDN 091539 Hutabayu as the perpetrators of the action. Data collection techniques in this study used creative thinking questionnaires and test essays to test the ability to write descriptive essays. The procedure of this research is filling out a creative thinking ability questionnaire, conducting a pretest, implementing an action, and doing a posttest. The results of this study indicate that the value of student description essay learning outcomes with high creative thinking abilities is higher than the value of students with low creative thinking abilities.
\end{abstract}

Keywords: creative thinking abilitie; descriptive essay writing.

Copyright (c) 2021 Yanti Arasi Sidabutar

$\triangle$ Corresponding author :

Email : arasiyanti@gmail.com

DOI : $\quad$ https://doi.org/10.31004/basicedu.v5i6.1658

ISSN 2580-3735 (Media Cetak)

ISSN 2580-1147 (Media Online) 
5380 Pengaruh Kemampuan Berpikir Kreatif terhadap Kemampuan Menulis Karangan Deskripsi Siswa Sekolah Dasar - Yanti Arasi Sidabutar

DOI: https://doi.org/10.31004/basicedu.v5i6.1658

\section{PENDAHULUAN}

Keterampilan dalam berbahasa terbagi atas dua yaitu berbahasa tulis dan lisan. Kajian tentang bahasa tulis, yang komponen-komponennya terdiri atas keterampilan membaca dan menulis yang merupakan keterampilan dasar yang diajarkan mulai dari kelas awal di Sekolah Dasar (SD) Siahaan et al., (2020); Musaddat et al., (2021). Menulis merupakan sebuah kegiatan kompleks hal ini dikarenakan penulis diharuskan untuk dapat menyusun dan mengelompokkan isi tulisan serta mewujudkannya dalam ragam bahasa tulis. Tetapi, aktivitas menulis hanya disukai beberapa siswa saja. Hal tersebut sesuai dengan pernyataan Lado (dalam Guntur Tarigan, (2013); Agustina, (2017). Menulis merupakan sebuah aktivitas penting dalam pembelajaran setelah membaca, ketika sesorang menulis pasti mempunyai suatu arah yang akan disampaikan. Menulis merupakan menggambarkan simbol-simbol grafik yang melukiskan suatu bahasa yang dipahami oleh sesorang, sehingga oranglain bias membaca simbol-simbol grafik tersebut jika mereka memahami bahasa dan gambaran grafik itu APRIYANTI, (2020);Ananda \& Fadhilaturrahmi,( n.d.)

Berdasarkan pengalaman peneliti saat melakukan observasi di SD Negeri 091537 Hutabayu, peneliti menemukan berbagai kendala yang berkaitan dengan keterampilan menulis deskripsi siswa, hal itu diperkuat dengan data yang diperoleh yaitu masih adanya beberapa siswa yang memiliki nilai kemampuan menulis deskripsi yang rendah, yaitu di bawah 70 .

Hal ini disebabkan siswa merasa bahwa aktivitas menulis deskripsi sebagai hal yang sulit, membosankan, menghabiskan waktu dan pikiran, minimnya semangat dan motivasi siswa untuk berlatih menulis, tidak tahunya siswa mengenai apa yang akan dituliskan karena kesulitan untuk memulai tulisan itu, takut melakukan suatu kesalahan serta teknik pembelajaran yang tradisional/ konvensional dan belum menggunakan teknik pembelajaran yang inovatif dinilai kurang bervariasi sehingga banyak siswa merasa bosan.

Berdasarkan kejadian tersebut, maka guru kelas V SDN 091537 Hutabayu mencari jalan keluar untuk meningkatkan keterampilan menulis deskripsi siswa dengan memperhatikan kemampuan berpikir kreatifnya. Dalam kegiatan PKM yang dilakukan oleh Hanandini, (2019) mengemukakan bahwa Sekolah lebih fokus kepada hasil belajar akademik. Siswa dikatakan mampu, memperoleh nilai yang tinggi. Siswa tidak dibiasakan untuk berpikir kreatif, sehingga kemampuan tersebut tidak dapat terlihat dan muncul dalam kehidupan sehari-hari.

Penelitian Bakır \& Öztekin, (2014);Sawyer, (2015);Abraham et al., (2019);Puccio et al., (2020)juga mendeskripsikan bahwa pembelajaran pada sebagian sistem pendidikan dipandang minim dalam mengembangkan pengajaran berbasis inovatif. Pendidik cenderung menghambat proses kreativitas dengan mengajak siswa untuk menghafal teori Alencar (dalam Ranjan \& Gabora, (2013). Sementara itu, Fakhriyani, (2016); Astuti \& Aziz, (2019); Andayani, (2021) mengatakan bahwa kreativitas merupakan keterampilan untuk membangun sebuah koalisi yang baru, berdasarkan informasi, atau komponen-komponen yang telah ada atau yang telah dikenal sebelumnya yaitu semua kejadian-kejadian dan semua pemahaman-pemahaman yang telah diperoleh seseorang semasa beraktivitas baik di wilayah pendidikan/sekolah, kerabat/keluarga maupun masyarakat. Pernyataan tersebut di dukung oleh WAHYU, (2021) yang juga berpendapat bahwa berpikir kreatif adalah berpikir dengan mengaitkan gagasan atau hal-hal yang sebelumnya tidak saling terkait.

Kreativitas yang tinggi akan menciptakan ide-ide yang lebih baik pula, maksudnya adalah semakin tinggi kreativitas seseorang semakin baik juga hasil yang diberikan dalam menulis karangan deskripsinya. Dengan adanya kemampuan berpikir kreatif, maka seorang akan mampu melahirkan buah pikiran serta imajinasi ke dalam sebuah tulisan karangan deskripsi.

Swartz dan Perkins dalam Setiawan, (2015) mengungkapkan bahwa berpikir yang benar maupun yang baik dapat dikonseptualisasikan dari kegiatan maupun aktivitas yang ditampilkan oleh seseorang. Dari anggapan di atas dapat ditarik sebuah kesimpulkan bahwa berpikir yang benar/baik akan memperlihatkan 
5381 Pengaruh Kemampuan Berpikir Kreatif terhadap Kemampuan Menulis Karangan Deskripsi Siswa Sekolah Dasar - Yanti Arasi Sidabutar

DOI: https://doi.org/10.31004/basicedu.v5i6.1658

seseorang mampu merangkai dan menciptakan sebuah kesimpulan yang terpercaya, memiliki pengetahuan yang luas, membuat kesimpulan yang cakap, menciptakan kreasi yang baik, dan invensi yang inovatif. Oleh karena itu untuk meningkatkan keterampilan menulis karangan deskripsi siswa maka perlu diperhatikan kemampuan berpikir kreatif siswa. Karena kemampuan berpikir kreatif sangat berpengaruh terhadap kemampuan siswa.

\section{METODE PENELITIAN}

Lokasi penelitian ini di SD Negeri 091537 Hutabayu. Subjek penelitian ini adalah siswa kelas V SDN 091537 Hutabayu Kabupaten Simalungun, semester genap Tahun Pelajaran 2019/2020, dimana jumlah siswa 23 orang, yaitu 11 orang siswa laki-laki dan 12 orang siswa perempuan.

Jenis penelitian ini adalah jenis penelitian eksperimen semu (quasi experiment). Penelitian eksperimen semu dilakukan untuk menguji hipotesis tentang ada tidaknya pengaruh suatu tindakan bila dibandingkan dengan tindakan lain dengan pengontrolan variabelnya sesuai dengan kondisi yang ada Purwanto \& Sulistyasturi, (2017); Prsetyo \& Jannah, (2019). Dalam penelitian ini peneliti ingin melihat suatu pengaruh sebuah variabel bebas berupa berpikir kreatif, dengan suatu variabel terikat, yaitu kemampuan menulis karangan deskripsi.

Desain penelitian yang digunakan adalah memakai tes awal (pretest) dan teks akhir (posttest). Di antara pretest $\left(O_{1}\right)$ dan posttest $\left(O_{2}\right)$ dilakukan suatu tindakan pengajaran pembelajaran untuk mengetahui bagaimana perbedaan sebelum diberikan tindakan dan sesudah diberikan tindakan (X). Hal itu dapat digambarkan di dalam desain The One Group Pretest posttest Design yang menggunakan suatu kelompok tindakan dengan memberikan pretest serta posttest.

Untuk menguji hipotesis penelitian ini digunakan teknik statistik infrensial, dengan teknik analisa varians dua jalur (Two Ways Anava) dengan taraf signifikansi $\alpha=0$,05.Analisis uji persyaratan dilakukan dengan menggunakan uji normalitas menggunakan uji Kolmogorof dan Saphiro-Wilk, dan uji homogenitas menggunakan uji Barlet t (Sugiyono, 2010).

\section{HASIL DAN PEMBAHASAN}

\section{Data Tes Awal (Pretes) Hasil Belajar Menulis Karangan Deskripsi Siswa Dengan Kemampuan Berpikir Kreatif Tinggi Dan Rendah}

Setelah dilakukan pengolahan data hasil pretes, diperoleh statistik deskriptif yang terdiri dari nilai maksimum, nilai minimum, rata-rata, simpangan baku dan varians. Di bawah ini disajikan statistik deskriptif data hasil menggunakan Software SPSS 22 for Window

Tabel 1. Statistik Deskriptif Data Tes Awal (Pretest)

\begin{tabular}{ccccccc}
\hline \multicolumn{7}{c}{ Descriptive Statistics } \\
\hline KBK Rendah Pretes & 13 & 40.00 & 75.00 & 715.00 & 55.0000 & 10.20621 \\
\hline KBK Tinggi Pretes & 11 & 58.00 & 77.00 & 773.00 & 70.2727 & 5.55141 \\
\hline Valid N (listwise) & 11 & & & & & \\
\hline
\end{tabular}

Tabel 1 diatas menunjukkan bahwa rerata pretes kemampuan menulis karangan deskripsi siswa dengan kemampuan berpikir rendah sebesar 55.00dan rerata pretes kemampuan menulis karangan deskripsi siswa dengan kemampuan berpikir kreatif tinggi sebesar 70.27. 
5382 Pengaruh Kemampuan Berpikir Kreatif terhadap Kemampuan Menulis Karangan Deskripsi Siswa Sekolah Dasar - Yanti Arasi Sidabutar

DOI: https://doi.org/10.31004/basicedu.v5i6.1658

Tabel 2. Uji Normalitas Data Pretes

\begin{tabular}{ccccccc}
\hline & \multicolumn{7}{c}{ Tests of Normality } & \multicolumn{3}{c}{ Shapiro-Wilk } \\
\cline { 2 - 7 } & Statistic & Df & Sig. & Statistic & df & Sig. \\
\hline KBKRendahPretes & .170 & 11 & $.200^{*}$ & .958 & 11 & .746 \\
\hline KBKTinggiPretes & .137 & 11 & $.200^{*}$ & .932 & 11 & .435 \\
\hline
\end{tabular}

Pada tabel 2 terlihat bahwa nilai normalitas siswa dengan kemampuan berpikir kreatif rendah sebesar 0,958 dengan signifikansi 0,200 karena signifikansi lebih besar dari 0,05 maka data pretes siswa dengan kemampuan berpikir kreatif rendah berdistribusi normal. Selanjutnya nilai normalitas siswa dengan kemampuan berpikir kreatif tinggi sebesar 0,932 dengan signifikansi 0,200 karena signifikansi lebih besar dari 0,05 maka data pretes siswa dengan kemampuan berpikir kreatif tinggiberdistribusi normal. Oleh karena itu dapat disimpulkan bahwa kedua sampel berdistribusi normal.

\section{Data Tes Akhir (Postes) Hasil Belajar Menulis Karangan Deskripsi Siswa Dengan Kemampuan Berpikir Kreatif Tinggi Dan Rendah}

Setelah dilakukan pengolahan data hasil pretest, maka dilakukan pengolhan pada data postest maka diperoleh statistik deskriptif yang terdiri dari nilai maksimum, nilai minimum, rata-rata, simpangan baku dan varians. Di bawah ini disajikan statistik deskriptif data tes akhir.

Tabel 3 Statistik Deskriptif Data Tes Akhir (Postes)

\begin{tabular}{lrrrrrr}
\hline \multicolumn{7}{c}{ Descriptive Statistics } \\
\hline & N & Minimum & Maximum & \multicolumn{1}{l}{ Sum } & Mean & Std. Deviation \\
\hline KBKRendahPostes & 13 & 55.00 & 85.00 & 890.00 & 68.4615 & 10.87517 \\
\hline KBKTinggiPostes & 11 & 80.00 & 90.00 & 923.00 & 83.9091 & 3.23897 \\
\hline Valid N (listwise) & 11 & & & & & \\
\hline
\end{tabular}

Pada tabel 3 diperoleh data yaitu nilai rata-rata dari 13 orang siswa yang mempunyai kemampuan berpikir kreatif rendah adalah 68.46. Sebaran data (Std. Deviation) yang diperoleh 10.87. nilai rata-rata siswa yang mempunyai kemampuan berpikir kreatif tinggi adalah 83.90. Sebaran data (Std. Deviation) yang diperoleh 3.23.

Tabel 4. Uji Normalitas Data Postes

\begin{tabular}{ccccccc}
\hline & \multicolumn{3}{c}{ Tests of Normality } & \multicolumn{3}{c}{ Shapiro-Wilk } \\
\cline { 2 - 7 } & Statistic & Df & Sig. & Statistic & df & Sig. \\
\hline KBKRendahPostes & .172 & 13 & $.200^{*}$ & .948 & 13 & .562 \\
\hline KBKTinggiPostes & .177 & 11 & $.200^{*}$ & .924 & 11 & .354 \\
\hline
\end{tabular}

Pada tabel 4 terlihat bahwa nilai normalitas posttest siswa dengan kemampuan berpikir kreatif rendahsebesar dengan signifikansi 0,200 karena signifikansi lebih besar dari 0,05 maka data pretest siswa dengan kemampuan berpikir kreatif rendah berdistribusi normal. Selanjutnya nilai normalitas siswa dengan kemampuan berpikir kreatif tinggidengan signifikansi 0,200 karena signifikansi lebih besar dari 0,05 maka data pretes siswa dengan kemampuan berpikir kreatif tinggiberdistribusi normal. Oleh karena itu dapat disimpulkan bahwa kedua sampel berdistribusi normal. 
5383 Pengaruh Kemampuan Berpikir Kreatif terhadap Kemampuan Menulis Karangan Deskripsi Siswa Sekolah Dasar - Yanti Arasi Sidabutar

DOI: https://doi.org/10.31004/basicedu.v5i6.1658

Tabel 5 Independent Sampel Test

Independent Samples Test

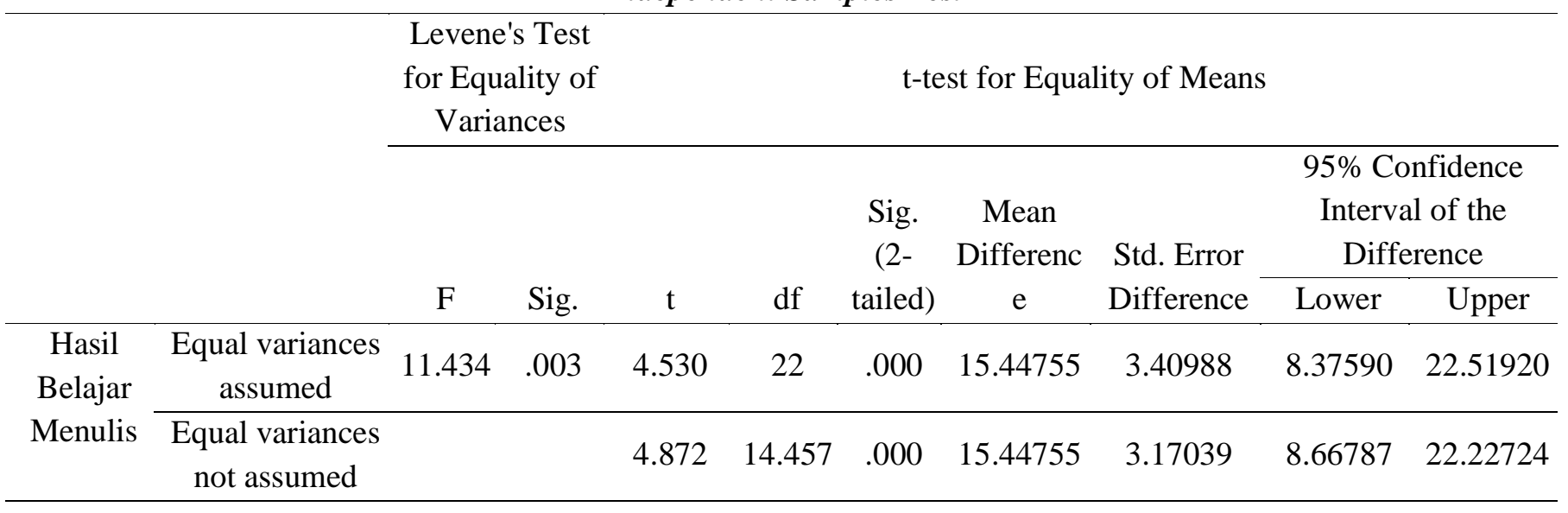

Tabel 5 merupakan hasil analisis dari independent sample test yang mengungkapkan bahwa nilai signifikansi sebesar 0,000. Karena sig. 0,000 $<0,05$ maka hasil dari uji hipotesis yaitu menolak $\mathrm{H}_{0}$ atau menerima $\mathrm{H}_{\mathrm{a}}$ dalam taraf alpha 5\%. Hal ini mengungkapkan bahwa adanya perbedaan yang signifikan antara hasil belajara menulis karangan deskripsi siswa dengan kemampuan berpikir kreatif rendah dan hasil belajar menulis deskripsi siswa dengan kemampuan berpikir kreatif rendah.

Kemampuan berpikir kreatif belajar sangat memiliki dampak terhadap peningkatan kemampuan menulis deskripsi siswa pada mata pelajaran Bahasa Indonesia. Hal ini dapat diketahui dari hasil temuan yang menguatkan bahwa siswa dengan kemampuan berpikir kreatif tinggi lebih memiliki kemauan untuk menciptkan sesuatu yang terkait dengan mata pelajaran Bahasa Indonesia. Selain itu, siswa dengan kemampuan berpikir kreatif tinggi aktif bertindak di kelas, sedangkan bagi siswa dengan kemampuan berpikir kreatif rendah lebih condong banyak menunggu, tidak aktif dan kurang bersifat inovatif.

Bersumber pada hasil penelitian yang diperoleh memberikan keterangan bahwa dalam hal kegiatan pembelajaran menulis deskripsi harus memperhatikan tingkat kemampuan berpikir kreatif siswa dengan serius karena keterampilan berpikir sangat memberikan efek terhadap hasil belajar siswa.

\section{KESIMPULAN}

Bersumber pada data yang sudah dipaparkan di atas dapat ditarik kesimpulan yaitu kemampuan berpikir kreatif merupakan sebuah kemampuan penting yang diharuskan dimiliki oleh tiap siswa dalam aktivitas menulis karangan deskripsi. Maknanya adalah jika tidak memiliki kemampuan berpikir kreatif yang mencukupi, maka siswa akan sulit untuk menuliskan ide dan gaasan mereka dalam sebuah karangan deskripsi.

Kesimpulan ini diperoleh berdasarkan hasil penelitian yang diperoleh yaitu adanya perbedaan yang signifikan antara hasil belajara menulis karangan deskripsi siswa dengan kemampuan berpikir kreatif rendah dan hasil belajar menulis deskripsi siswa dengan kemampuan berpikir kreatif rendah. Dimana hasil menulis karangan narasi siswa dengan kemampuan berpikir kreatif tinggi memiliki nilai rerata $(X=83.90)$ lebih tinggi dari siswa yang memiliki kemampuan berpikir kreatif belajar rendah dengan nilai rerata $(X=68.46)$, dan kemampuan berpikir kreatif memiliki perbedaan yang signifikan d hasil belajara menulis karangan deskripsi siswa. 
5384 Pengaruh Kemampuan Berpikir Kreatif terhadap Kemampuan Menulis Karangan Deskripsi Siswa Sekolah Dasar - Yanti Arasi Sidabutar

DOI: https://doi.org/10.31004/basicedu.v5i6.1658

\section{UCAPAN TERIMA KASIH}

Terima kasih untuk Ibu Dr (Cand). Tarida Alvina Simanjuntak, M.Pd yang meluangkankan waktu untuk arahan pembuatan artikel ini dan seluruh bantuan dari teman-teman yang namuanya tidak bisa disebutkan satu persatu. Tanpa arahan dan bantuan tersebut peneliti tidak dapat menyelesaikan artikel ini.

\section{DAFTAR PUSTAKA}

Abraham, A., Asquith, S., Ahmed, H., \& Bourisly, A. K. (2019). Comparing The Efficacy Of Four Brief Inductions In Boosting Short-Term Creativity. Journal Of Cognitive Enhancement, 3(1), 85-93.

Agustina, E. S. (2017). Pembelajaran Bahasa Indonesia Berbasis Teks: Representasi Kurikulum 2013. Aksara: Jurnal Bahasa Dan Sastra, 18(1).

Ananda, R., \& Fadhilaturrahmi, F. (N.D.). Analisis Kemampuan Guru Sekolah Dasar Dalam Implementasi Pembelajaran Tematik Di Sd. Jurnal Basicedu, 2(2), 11-21.

Andayani, S. (2021). Bermain Sebagai Sarana Pengembangan Kreativitas Anak Usia Dini. Jurnal An-Nur: Kajian Ilmu-Ilmu Pendidikan Dan Keislaman, 7(01), 230-238.

Apriyanti, Y. (2020). Hubungan Penggunaan Media Grafis Terhadap Keterampilan Menulis Teks Iklan Siswa Kelas Viii Smp-Negeri 2 Nanga Pinoh Kabupaten Melawi. Ikip Pgri Pontianak.

Astuti, R., \& Aziz, T. (2019). Integrasi Pengembangan Kreativitas Anak Usia Dini Di Tk Kanisius Sorowajan Yogyakarta. Jurnal Obsesi: Jurnal Pendidikan Anak Usia Dini, 3(2), 294-302.

Bakır, S., \& Öztekin, E. (2014). Creative Thinking Levels Of Preservice Science Teachers In Terms Of Different Variables. Journal Of Baltic Science Education, 13(2), 231.

Fakhriyani, D. V. (2016). Pengembangan Kreativitas Anak Usia Dini. Wacana Didaktika, 4(2), 193-200.

Guntur Tarigan, H. (2013). Pengajaran Gaya Bahasa. Bandung: Penerbit Angkasa.

Hanandini, D. A. (2019). Implementasi Strategi Every One Is A Teacher Here Dalam Meningkatkan Keaktifan Siswa Pada Mata Pelajaran Fiqih Kelas Viii Madrasah Tsanawiyah Negeri 3 Ponorogo Semester Genap Tahun 2018/2019. Iain Ponorogo.

Musaddat, S., Suarni, N. K., Dantes, N., Putrayasa, I. B., \& Dantes, G. R. (2021). Kelayakan Pengembangan Bahan Ajar Digital Berkearifan Lokal Sebagai Bahan Literasi Bahasa Berbasis Kelas Serta Pengaruhnya Terhadap Karakter Sosial Dan Keterampilan Berbahasa Siswa Sekolah Dasar. Jurnal Ilmiah Mandala Education, 7(3).

Prsetyo, B., \& Jannah, L. M. (2019). Metode Penelitian Kuantitatif.

Puccio, G. J., Burnett, C., Acar, S., Yudess, J. A., Holinger, M., \& Cabra, J. F. (2020). Creative Problem Solving In Small Groups: The Effects Of Creativity Training On Idea Generation, Solution Creativity, And Leadership Effectiveness. The Journal Of Creative Behavior, 54(2), 453-471.

Purwanto, E. A., \& Sulistyasturi, D. R. (2017). Metode Penelitian Kuantitatif.

Ranjan, A., \& Gabora, L. (2013). Creative Ideas For Actualizing Student Potential. In Teaching Creatively And Teaching Creativity (Pp. 119-131). Springer.

Sawyer, K. (2015). A Call To Action: The Challenges Of Creative Teaching And Learning. Teachers College Record, 117(10), 1-34.

Setiawan, W. (2015). Meningkatkan Kemampuan Berpikir Kritis Matematis Siswa Smp Dengan Menggunakan Model Penemuan Terbimbing. Jurnal Ilmiah P2m Stkip Siliwangi, 2(1), 91-97.

Siahaan, K. W. A., Sinabutar, A. T., \& Haloho, U. N. (2020). Pengaruh Metode Quantum Teaching Dalam Menciptakan Pembelajaran Yang Aktif Dan Menyenangkan Pada Anak Sd. Jurnal Elementaria Edukasia, 3(2). 
5385 Pengaruh Kemampuan Berpikir Kreatif terhadap Kemampuan Menulis Karangan Deskripsi Siswa Sekolah Dasar - Yanti Arasi Sidabutar

DOI: https://doi.org/10.31004/basicedu.v5i6.1658

Sugiyono, P. D. (2010). Statistika Untuk Penelitian. Bandung: Alfabeta.

Wahyu, R. (2021). Analisis Kemampuan Wirausaha Dan Peluang Usaha Terhadap Keberhasilan Usaha Pada Kegiatan Pelaku Ukm Binaan Ukm Center Universitas Pembangunan Panca Budi Medan. Kumpulan Karya Ilmiah Mahasiswa Fakultas Sosial Sains, 1(01). 